MARCIN OLSZEWSKI

Poznań University of Economics and Business, Poland

\title{
Scientists' attitudes towards academic entrepreneurship: the results of an empirical study
}

\begin{abstract}
In recent years, there has been growing pressure on both universities and enterprises to intensify cooperation. The subject of this article here is academic entrepreneurship at the researcher level. The aim is to identify attitudes towards such entrepreneurship and define the diversity of attitudes. Moreover, it has been established how such attitudes towards entrepreneurship differentiate the intention and commitment to start cooperation with industry in reality. Achieving this aim required an empirical study involving primary sources. The study subjects were university researchers working on tourism issues, and a total of 73 participated. Methods from descriptive statistics and the chi-square test of independence were used to analyse the results. According to the study, researchers are much more likely to perceive the benefits than the disadvantages of cooperation, and the benefits perceived most are chances to obtain information and the inspiration to conduct academic and didactic work. The work also found that researchers who see academic entrepreneurship as an opportunity for financial benefit and see cooperation as an opportunity to increase enterprises' competitive advantage significantly more often declare their intention to engage in it.
\end{abstract}

Keywords: academic entrepreneurship; attitude; entrepreneurial researcher; theory of planned behaviour; tourism industry

Received: 1 November 2021

Accepted: 2 March 2021

\section{Suggested citation:}

Olszewski, M. (2021). Scientists' attitudes towards academic entrepreneurship: the results of an empirical study. Przedsiębiorczość - Edukacja [Entrepreneurship - Education], 17(1), 7-18. https://doi.org/10.24917/20833296.171.1

\section{Introduction}

In the knowledge-based economy, universities increasingly become an essential element of innovation systems (Etzkowitz et al., 2000). As a result, cooperation with external stakeholders is growing, and universities are evolving towards 'entrepreneurial universities'. 
Changes in the model of a university's functioning result from internal factors inherent in the education and research system, changes in the external environment, and the need to cope with new economic challenges. The most critical factors in the evolution towards an entrepreneurial university include globalisation, the development of information technologies, the weakening of the state's role as the university guardian, and limitations to financing from public funds (Boguski, 2009; Wiśniewska, 2014).

The subject for discussion here is academic entrepreneurship at the researcher level, and the aim is to identify attitudes towards academic entrepreneurship and assess their diversity and effects. Moreover, how attitudes towards entrepreneurship differentiate the actual intention and commitment to start cooperation with the industry was investigated.

The article consists of four parts, preceded by an introduction and concluded with a summary. The first part introduces the concept of academic entrepreneurship, the second presents the benefits of entrepreneurial activity identified based on previous research, the next one presents the methodology of the empirical research, and the final one discusses the results. The article ends with a summary and proposals for further research on the issue of academic entrepreneurship.

\section{The essence of academic entrepreneurship}

Due to the growing importance of academic entrepreneurship, there is a need to research the determinants of the academic researchers' entrepreneurial behaviour (Goethner et al., 2012; Rothaermel, Agung, Jiang, 2007). Previous studies emphasises academic entrepreneurship's distinctiveness from other forms (Goethner et al., 2012). F.T. Rothaermel, S.D. Agung and L. Jiang (2007) broadly define academic entrepreneurship as universities' activity related to creating new companies, patents and facilitating transfer by creating incubators and science parks. According to M. Abreu and V. Grinevich (2017), academic entrepreneurship is the commercial use of scientific research. Thus, the entrepreneurship of modern universities has a dual character. On the one hand, the university itself as an institution becomes entrepreneurial, and on the other, its employees and students become transformed into entrepreneurs (Marszałek, 2009).

In a narrow sense, the concept of academic entrepreneurship is defined as establishing companies by university employees and students (and sometimes even its graduates) (Hayter et al., 2018; Shane, 2004). However, over the years, such a narrow understanding has been supplemented with other activity forms related to the commercial use of knowledge created at universities. In a broad sense, academic entrepreneurship should be understood as the involvement in relations with entities from the external environment within the so-called third mission of the university. According to Abreu and Grinevich (2013), the understanding of academic entrepreneurship should be broadened to include any research activity beyond the traditional roles related to research and teaching and which leads to financial benefits for the researcher's university. The financial benefits obtained may be direct or indirect, e.g. by increasing reputation, prestige or influence. Similarly, S. Jain et al. (2009) believe that any form of knowledge transfer with potential financial benefits can be referred to as academic entrepreneurship. H. Etzkowitz (1998) believes that an entrepreneurial researcher has an entrepreneurial perspective and uses it to evaluate research results in terms of commercialisation potential. E. Albats et al. (2018) suggest that it is a member of the academic community who adopts an entrepreneurial outlook 
expressed in searching for opportunities to achieve research and teaching goals through cooperation with business partners.

Recently, there has been a noticeable increase in universities' and enterprises' expectations related to intensifying cooperation. For enterprises, this results from competitive pressure and the need to improve products and processes' innovativeness. In turn, universities are looking for funds for research activities and cooperate under the influence of social pressure related to expectations of intensifying economic development thanks to the knowledge created at universities (Ankrah, AL-Tabbaa, 2015). Therefore, researching academic attitudes towards entrepreneurship may clarify the scope of involvement in cooperation with the industry.

\section{Perceived benefits and threats of researchers' entrepreneurial involvement}

One of the concepts explaining entrepreneurial behaviour is I. Ajzen's (1991) theory of planned behaviour which shows the relationship between action and intention and its determinants. Behavioural intention is influenced by attitudes towards behaviour, subjective norms and perceived control of the action. The theory of planned behaviour has been used to explain general entrepreneurial behaviour (Liñán, Chen, 2009) and researchers' specific behaviour (Goethner et al., 2012; Miranfrda et al., 2017). One of the determinants of intention is the attitude towards a given action, where attitude is the degree to which a person favourably or unfavourably assesses a given action and its effects. According to Ajzen (1991), the more positive the attitude towards action, the stronger the intention to undertake it. As shown by previous research, academics are more likely to become involved in relationships with entities from the external environment if they positively assess entrepreneurial approaches to the use of academic knowledge (Goethner et al., 2012).

Previous studies, which used the theory of planned behaviour to explain entrepreneurial behaviour, indicate that it explains $30-45 \%$ of entrepreneurial intention variability (Saeed et. al, 2015). In the research on academic entrepreneurship, these figures reach 57\% (Miranda, Chamorro-Mera, Rubio, 2017).

The importance of attitudes in explaining entrepreneurial behaviour justifies researcher opinions on the benefits and threats of cooperation with business. A summary of the work conducted so far on the perception of academic entrepreneurship's advantages and disadvantages is presented in Table 1.

Academic entrepreneurship may be perceived through the lens of its benefits, both financial and non-financial. The latter include the possibility of researching enterprises, joint publications with businesses, access to enterprise infrastructure, testing ideas in practice and enriching didactics (Ankrah, AL-Tabbaa, 2015; Marszałek, 2014).

P. D'Este and M. Perkmann (2011) found that the main benefit of prompting cooperation is a research motive. However, the assessment of the effects of cooperation may differ depending on the knowledge transfer channel. Specific forms of entrepreneurial activity are mainly financially motivated, such as setting up spin-off companies and patenting the results, but others are scientifically based. Research conducted at universities in Brazil shows that cooperation allows developing and transferring new technologies and new knowledge (Bodas Freitas, Marques, Silva, 2013). This work also shows that researchers claim that financial incentives and access to research funding are less critical. Other work confirms strong relationships between maintaining connections between businesses and 
academic activity. Siegel et al. (2004), in a study conducted in American universities, found that there is a positive relationship between cooperation with enterprises and the quality of basic research. The transfer of knowledge from universities to enterprises is accompanied by a flow of information and knowledge the other way. Researchers treat collaboration as an opportunity to collect the data necessary for academic work or as an inspiration and source of knowledge about current problems and practical challenges. As a result, those involved in business relations publish more than those who do not conduct joint projects with practice (Van Looy et al. 2004). R. Welsh et al. (2008), based on indepth interviews with academics from biotechnology universities in the US, determined that among the most considerable expected cooperation benefits were access to research funds, new research tools and support for students.

Table 1. Perceived effects of entrepreneurial engagement

\begin{tabular}{|l|l|}
\hline \multicolumn{1}{|c|}{\begin{tabular}{c}
\multicolumn{1}{|c|}{ Perceived effects } \\
of entrepreneurial engagement
\end{tabular}} & \multicolumn{1}{c|}{ Source example } \\
\hline Increase in the university's prestige & $\begin{array}{l}\text { Rohrbeck, Arnold (2006); Sobaih, Jones } \\
(2015)\end{array}$ \\
\hline Data sources for research activities & Rohrbeck, Arnold (2006); Siegel et al. (2004) \\
\hline $\begin{array}{l}\text { Improving academic productivity } \\
\text { (number of publications) }\end{array}$ & Van Looy et al. (2004) \\
\hline Improving the financial situation of researchers & $\begin{array}{l}\text { D'Este, Perkmann (2011); Sobaih, Jones, } \\
\text { (2015) }\end{array}$ \\
\hline Sourcing of finance for academic activities & $\begin{array}{l}\text { D'Este, Perkmann (2011); Rohrbeck, Arnold } \\
\text { (2006); Lai, Lu (2016); Welsh et al. (2008) }\end{array}$ \\
\hline Increasing the quality of teaching activities & $\begin{array}{l}\text { Caloghirou, Tsakanikas, Vonortas (2001); } \\
\text { D'Ambrosio et al. (2017); D'Este, Patel } \\
\text { (2007); Lai, Lu (2016); Rohrbeck, Arnold } \\
\text { (2006); Sobaih, Jones, (2015) }\end{array}$ \\
\hline $\begin{array}{l}\text { Increasing the chances of employing students } \\
\text { and graduates }\end{array}$ & $\begin{array}{l}\text { Hudson, Meng, Cárdenas, So (2017); } \\
\text { Rohrbeck, Arnold (2006); Welsh, Glenna, } \\
\text { Lacy, Biscotti (2008) }\end{array}$ \\
\hline $\begin{array}{l}\text { Accessing enterprises' infrastructure necessary } \\
\text { to conduct research }\end{array}$ & $\begin{array}{l}\text { Caloghirou, Tsakanikas, Vonortas (2001); } \\
\text { D'Este, Patel (2007); Welsh et al. (2008) }\end{array}$ \\
\hline $\begin{array}{l}\text { Time-consuming activity that limits the } \\
\text { opportunities to do research }\end{array}$ & Anatan (2013); Nelson (2004) \\
\hline $\begin{array}{l}\text { The influence of entrepreneurs on the subject of } \\
\text { research (restriction of freedom) }\end{array}$ & Behrens, Gray (2001) \\
\hline Pressure not to disclose research results & Carayol (2003); Nelson (2004) \\
\hline
\end{tabular}

Source: author based on the literature

I.K.W. Lai and Lu (2016), in a study conducted in Taiwan in the creative sector, found that for researchers, the fundamental motives for starting cooperation with the industry are financial benefits and support for educational activities. The work done so far shows that universities treat cooperation as an alternative to public funding and a source of finance for research activities. The interviews among representatives from universities in Egypt show that one of the expected effects of cooperation with the tourism industry is improving researchers' financial situation as a professional group with relatively low 
salaries (Sobaih, Jones, 2015). Moreover, researchers see an opportunity to improve professional competences, which, in their opinion, will translate into an improvement in the quality of education (Sobaih, Jones, 2015).

F. Rossi, A. Rosli and N. Yip (2017) indicate different ways of assessing the effects of knowledge transfer and entrepreneurial involvement. They are more concrete and measurable in reality, and they appear relatively shortly after establishing a relationship and the transfer of knowledge. The effects of a researcher's involvement are more challenging to quantify. Firstly, these effects are smaller than in the case of knowledge transfer and, secondly, they are often deferred in time. Long-term cooperation between practitioners and researchers, accompanied by an atmosphere of mutual trust, leads to a change in both parties' way of thinking. Such a change in perception over time is reflected in behavioural change.

Research on the entrepreneurial commitment of researchers shows that such activity carries certain risks. Firstly, when researchers start working for a business, they devote their limited time, which they cannot, as a result, spend on basic tasks such as research and teaching (Anatan, 2013). With the growing interest in collaborating with the industry, researchers are beginning to focus more on current, practical problems and less on basic research's fundamental issues (Nelson, 2004). As a result, universities' autonomy may decrease and, due to the growing role of finance from businesses, may be forced to carry out research commissioned by enterprises. Research freedom may also be limited by the imposition of research directions and topics (Behrens, Gray, 2001).

Another problem is the potential conflict of interest related to the publication of the results of joint research. Researchers may strive to make the obtained results public in publications and presentations at academic conferences. Enterprises whose goal is to obtain a permanent, i.e. difficult to imitate, competitive advantage will keep the work results carried out as a secret available only to them. Such a conflict is confirmed by the work carried out by P. Dasgupta and P. David (1994). D. Blumenthal (1996) found in a study of researchers in the life sciences that there was pressure from companies to delay publishing collaborative research results. Entrepreneurs expect that researchers will share their conclusions only when competitors' risk of copying solutions is gone, for example, guaranteeing secrecy until the end of a long-term patent.

Other threats most frequently indicated include conflicts between researchers (resulting from differences in involvement in relationships), failure to disclose the fact and scale of involvement, the need to choose between research work and gainful activity (Gulbrandsen, Smeby, 2005). K. Philpott (2011) also add challenges with limiting research and teaching time and increased requirements related to keeping business secrets. As a result, there is a threat of limitation or loss of the researcher's academic freedom (Rothaermel, Agung, Jiang, 2007). However, other studies have not confirmed that commercial involvement in relationships occurs at the expense of the researcher's remaining tasks (Van Looy et al., 2004).

The theory of planned action (Ajzen, 1991) assumes a relationship between attitudes towards a given activity, the intention to take any action and the actual action. As a result of the above discussion, the following two detailed research questions were formulated:

1. Is there a relationship between attitudes towards academic entrepreneurship and the intention to start cooperation with enterprises? 
2. Is there a relationship between attitudes towards academic entrepreneurship and actual involvement in cooperation with enterprises?

Conducting a primary source study using the diagnostic survey method was necessary to obtain answers to these questions.

\section{Research methodology}

The issue of entrepreneurial attitudes and their impact on researchers' entrepreneurial commitment has rarely been discussed in social disciplines (Sobaih, Jones, 2015). This article, however, covers researchers who are related to issues of tourism. Based on the website Science in Poland run by the Information Processing Center (OPI), a database of researchers in tourism was prepared, i.e. those who declared their relationship with tourism at the level of academic specialisation. The search engine available on the OPI website was used to identify them, thanks to which the respondents' contact details were obtained. An invitation to participate in the study was sent to 325 people.

Data was collected in the first half of 2018. The tool used was an electronic questionnaire sent in the form of a link and an introductory letter, together with an individual invitation to participate in the study. The study was preceded by testing the research tool. A total of 73 people participated.

Researchers' entrepreneurial commitment and intention to engage were assessed with a dichotomous scale. The dependent variable was the attitude of researchers towards academic entrepreneurship. A gradual order scale was used, indicating the degree to which the respondent agrees or disagrees with the definition of academic entrepreneurship. Descriptive statistical methods and chi-square tests of independence were used to analyse the results. By comparing the values of the deviations of the obtained figures from expected values, conclusions can be drawn about the existence of dependencies in the distribution of responses.

\section{The research results}

An analysis of attitudes towards academic entrepreneurship' diversity and effects were required to achieve the goal and obtain answers to the research questions. Table 2 presents a summary showing researchers' attitudes towards academic entrepreneurship, i.e. what they perceive as the positive and negative effects of entrepreneurial involvement.

As shown in Table 2, researchers perceive many more benefits of cooperation than disadvantages. The benefits perceived most often include obtaining information and the inspiration to conduct academic and didactic research. The researchers also see the importance of such cooperation for enterprises, both in competitiveness and ability to create innovations. To a lesser extent, the advantages bring personal benefits such as increased prestige or financial benefits. What is positive in future collaboration is that researchers do not share negative views about entrepreneurial engagement. They do not see cooperation as a deviation from ideals favouring the pursuit of profit, and they do not see cooperation as a source of tension and conflict. Moreover, in their opinion, cooperation takes time and hinders basic research to a small extent only.

Differentiation of researchers' attitudes towards entrepreneurship was also examined in terms of gender, age, academic title, and academic centre size. For this purpose, the 
chi-square test of independence was used. The one variable which significantly differentiates attitudes towards entrepreneurship is gender, as shown in Table 3. It shows that women see the possibility of enriching didactic activity through entrepreneurial involvement to a greater extent $\left(\chi^{2}(2)=7.162, p=0.028\right)$. They also see benefits for cooperating with enterprises more often relating to increasing innovation $\left(\chi^{2}(2)=7.165, p=0.028\right)$. The factor that distinguishes women from men the most is perceived pressure to cooperate, and the statistics show that women notice such pressure significantly more often than men $\left(\chi^{2}(2)=8.554, p=0.014\right)$. In the subgroup of researchers who feel pressure, women constitute $63.6 \%$, compared to $41.1 \%$ in the entire study group.

Table 2. Researchers' attitudes towards academic entrepreneurship

\begin{tabular}{|l|c|c|c|c|c|}
\cline { 2 - 6 } \multicolumn{1}{l|}{} & N & Min. & Max. & Mean & SD \\
\hline $\begin{array}{l}\text { it is a source of information and inspiration to } \\
\text { conduct academic research }\end{array}$ & 73 & 1 & 5 & 4.27 & 0.917 \\
\hline $\begin{array}{l}\text { it is a source of information and inspiration for } \\
\text { didactic work }\end{array}$ & 73 & 1 & 5 & 4.26 & 1.054 \\
\hline $\begin{array}{l}\text { it is a source of competitive advantage for } \\
\text { cooperating tourism enterprises }\end{array}$ & 73 & 2 & 5 & 3.85 & 1.023 \\
\hline $\begin{array}{l}\text { it increases the researcher's prestige } \\
\text { it contributes to the creation of innovation in } \\
\text { enterprises }\end{array}$ & 73 & 1 & 5 & 3.79 & 1.054 \\
\hline $\begin{array}{l}\text { it brings financial benefits to the researcher } \\
\text { it is beneficial from the perspective of career } \\
\text { advancement }\end{array}$ & 73 & 1 & 5 & 3.75 & 1.024 \\
\hline $\begin{array}{l}\text { it allows you to obtain funds for research } \\
\text { it is necessary due to socio-political pressure }\end{array}$ & 73 & 1 & 5 & 3.12 & 1.235 \\
\hline $\begin{array}{l}\text { it hinders the conduct of basic research takes } \\
\text { time) }\end{array}$ & 73 & 1 & 5 & 2.58 & 1.212 \\
\hline $\begin{array}{l}\text { it is a source of tensions and conflicts between } \\
\text { university employees }\end{array}$ & 73 & 1 & 5 & 2.45 & 1.119 \\
\hline $\begin{array}{l}\text { it is a departure from academic ideals in favour of } \\
\text { the pursuit of profit }\end{array}$ & 73 & 1 & 5 & 2.12 & 1.105 \\
\hline
\end{tabular}

Source: author based on empirical research

Table 3. Differentiation of attitudes due to the gender of the respondents

\begin{tabular}{|l|c|c|c|}
\cline { 2 - 3 } \multicolumn{1}{c|}{} & Females & Males & \multirow{2}{*}{ Chi-square test } \\
\hline Share in the studied population & $41.1 \%$ & $58.9 \%$ & \\
\hline Didactic inspiration & $46.9 \%$ & $53.1 \%$ & $\chi^{2}(2)=7.162, \mathrm{p}=0.028$ \\
\hline Innovations & $46.7 \%$ & $53.3 \%$ & $\chi^{2}(2)=7.165, \mathrm{p}=0.028$ \\
\hline Pressure & $63.6 \%$ & $36.4 \%$ & $\chi^{2}(2)=8.554, \mathrm{p}=0.014$ \\
\hline
\end{tabular}

Source: author based on empirical research

Attitudes towards entrepreneurship affecting the intention to start cooperation and the actual involvement in relations with the industry were also examined. Table 4 presents the attitudes towards academic entrepreneurship, which significantly differentiate 
the intention to start cooperation. The study found that researchers significantly more often declare their intention to engage when they perceive academic entrepreneurship as a chance to gain financial benefits $\left(\chi^{2}(2)=5.964, \mathrm{p}=0.0507\right)$ and perceive cooperation as an opportunity to increase the competitive advantage of enterprises $\left(\chi^{2}(2)=6.889\right.$, $\mathrm{p}=0.032$.

Table 4. Differentiation of attitudes due to the intention to start cooperation

\begin{tabular}{|l|c|c|c|}
\hline \multicolumn{1}{|c|}{ Question 1 } & $\begin{array}{c}\text { Negative } \\
\text { intention }\end{array}$ & $\begin{array}{c}\text { Positive } \\
\text { intention }\end{array}$ & \multirow{2}{*}{ Chi-square test } \\
\cline { 1 - 2 } $\begin{array}{l}\text { Share in the studied } \\
\text { population }\end{array}$ & $25 \%$ & $75 \%$ & \\
\hline Financial benefits & $13.4 \%$ & $86.6 \%$ & $\chi 2(2)=5.964, \mathrm{p}=0.0507$ \\
\hline Competitive advantage & $17.5 \%$ & $82.5 \%$ & $\chi 2(2)=6.889, \mathrm{p}=0.032$ \\
\hline
\end{tabular}

Source: author based on empirical research

Table 5. Differentiation of attitudes due to the actual involvement of respondents in cooperation

\begin{tabular}{|l|c|c|c|}
\hline \multicolumn{1}{|c|}{ Question 2 } & Not engaged & Engaged & \multirow{2}{*}{ Chi-square test } \\
\cline { 1 - 2 } $\begin{array}{l}\text { Share in the studied } \\
\text { population }\end{array}$ & $27.4 \%$ & $72.6 \%$ & \\
\hline Prestige & $21.3 \%$ & $78.7 \%$ & $\chi 2(2)=7.719, \mathrm{p}=0.021$ \\
\hline
\end{tabular}

Source: author based on empirical research

As shown in Table 5, those who assess entrepreneurial involvement as a prestige source are more likely to engage in cooperation $\left(\chi^{2}(2)=7.719, \mathrm{p}=0.021\right)$.

\section{Conclusions}

Researchers whose primary task is to conduct research and didactic activity increasingly see the need to cooperate with external stakeholders. Success in cooperation between universities and enterprises in knowledge transfer depends on many factors, with A. Agrawal (2001) emphasising the importance of researching individual motives and the conditions for researchers' involvement in cooperation with entities from the external environment.

The obtained results indicate that researchers formulate positive attitudes towards academic entrepreneurship. The perceived benefits mainly concern the possibility of enriching academic and didactic activities thanks to relations with businesses, which confirms previous research results, including D.S. Siegel et al. (2004) and Lai and Lu (2016).

According to the survey, engagement in academic entrepreneurship is influenced by its perception. The intention to start cooperation is significantly greater among researchers who see financial benefits in cooperation and perceive it as an opportunity to increase enterprises' competitiveness. Moreover, actual involvement in entrepreneurial activity is significantly greater among researchers who see a source of prestige in such cooperation. As a result, it can be concluded that the answer to both research questions is partially positive. 
It should be emphasised that the benefits of academic entrepreneurship perceived most often do not significantly impact intention and commitment. Only financial benefits and those for enterprises have a significant impact on the intention to start cooperation. A.E. Sobaih, E. Jones (2015) reached similar conclusions based on a study conducted among researchers dealing with tourism.

The benefits of cooperation may be long-term or short-term (Arza, 2010). Long-term benefits are most often associated with opportunities to access new knowledge, and this allows teaching activities to be enriched, research to be conducted, or it can be an inspiration for future research (Arza, Carattoli, 2017). Short-term benefits are financial and can be an opportunity to obtain additional funds for the researcher's research or individual benefits. This article confirms that obtaining funds is one of the essential benefits of involvement in relations with external environment entities (Etzkowitz et al., 2000; Perkmann, Walsh, 2009).

Attitudes towards entrepreneurship are not constant, and they change over time. As indicated, for instance, by Etzkowitz (1998), the negative perception of obtaining financial benefits from such cooperation is replaced by a positive perception of entrepreneurial behaviour. Further work on researchers' attitudes towards entrepreneurship should be dynamic and take into account trends in attitudes. It should also consider the simultaneous role of all the determinants of intention and actual action as indicated in the theory of planned behaviour by Ajzen (1991), i.e. attitudes towards behaviour, subjective norms and perceived action control. Moreover, the factors influencing academic entrepreneurship in the stricter sense, e.g. establishing spin-off companies, which is relatively the rarest form of entrepreneurial activity, are worth examining. It is also necessary to expand the research scope and include researchers from other disciplines and research areas.

Involvement in knowledge transfer is most often treated as a mission complementary to universities' traditional activities, i.e. teaching and research. Etzkowitz et al. (2000) emphasise that universities should find a balance between traditional and entrepreneurial activities. The main challenge in university management is to support researchers' entrepreneurial commitment in such a way as not to lose control over the traditional mission or limit the freedom of research.

\section{References}

Abreu, M., Grinevich, V. (2017). Gender patterns in academic entrepreneurship. Journal of Technology Transfer, 42(4), 763-794. doi: 10.1007/s10961-016-9543-y

Abreu, M., Grinevich, V. (2013). The nature of academic entrepreneurship in the UK: Widening the focus on entrepreneurial activities. Research Policy, 42(2), 408-422. doi: 10.1016/j.respol.2012.10.005

Agrawal, A. (2001). University-to-industry knowledge transfer: literature review and unanswered questions. International Journal of Management Reviews, 3(4), 285-302. doi: 10.1111/1468-2370.00069

Ajzen, I. (1991). The Theory of Planned Behavior. Organizational Behavior and Human Decision Processes, 50(2), 179-211. doi: 10.1016/0749-5978(91)90020-T

Albats, E., Alexander, A., Cunningham, J. A., Miller, K. (2018). Entrepreneurial academics and academic entrepreneurs: a systematic literature review. International Journal of Technology Management, 77(1/2/3), 9-37. https://doi.org/10.1504/IJTM.2018.10012933

Anatan, L. (2013). A Proposed Framework of University to Industry Knowledge Transfer. Review of Integrative Business and Economics, 2(2), 304-325. 
Ankrah, S., AL-Tabbaa, O. (2015). Universities-industry collaboration: A systematic review. Scandinavian Journal of Management, 31(3), 387-408. doi: 10.1016/j.scaman.2015.02.003

Arza, V. (2010). Channels, benefits and risks of public-private interactions for knowledge transfer: Conceptual framework inspired by Latin America. Science and Public Policy, 37(7), 473-484. doi: $10.3152 / 030234210 X 511990$

Arza, V., Carattoli, M. (2017). Personal ties in university-industry linkages: a case-study from Argentina. Journal of Technology Transfer, 42(4), 814-840. doi: 10.1007/s10961-016-9544-x

Behrens, T.R., Gray, D.O. (2001). Unintended consequences of cooperative research: Impact of industry sponsorship on climate for academic freedom and other graduate student outcomes. Research Policy, 30(2), 179-199. doi: 10.1016/S0048-7333(99)00112-2

Blumenthal, D., Campbell, E., Causino, N., Louis, K. (1996). Participation of life science faculty in research relationships with industry. New England Journal of Medicine, 335(23), 1734-1739. doi: 10.1056/NEJM199612053352305

Bodas Freitas, I.M., Marques, R.A., Silva, E. (2013). University-industry collaboration and innovation in emergent and mature industries in newly industrialized countries. Research Policy, 42(2), 443-453. doi: 10.1016/j.respol.2012.06.006

Boguski, J. (2009). Od uniwersytetu tradycyjnego do uniwersytetu przyszłości. Nauka i Szkolnictwo Wyższe, 1(33), 25-33.

Caloghirou, Y., Tsakanikas, A., Vonortas, N.S. (2001). University-Industry Cooperation in the Context of the European Framework Programmes. The Journal of Technology Transfer, 26, 153-161. doi: 10.1023/A:1013025615518

Carayol, N. (2003). Objectives, agreements and matching in science-industry collaborations: Reassembling the pieces of the puzzle. Research Policy, 32(6), 887-908. doi: 10.1016/S00487333(02)00108-7

D’Ambrosio, L., Halberg Madsen, J., Wejrum, L.M. (2017). Knowledge Transfer between Educational Institutions and Destinations. Bridging Tourism Theory and Practice, 8, 59-72. doi: 10.1108/S2042144320170000008005

Dasgupta, P., David, P. (1994). Towards a New Economics of Science. Research Policy, 23(5), 487-522. doi: 10.1016/0048-7333(94)01002-1

D’Este, P., Perkmann, M. (2011). Why do academics engage with industry? The entrepreneurial university and individual motivations. Journal of Technology Transfer, 36(3), 316-339. doi: 10.1007/ s10961-010-9153-Z

Etzkowitz, H. (1998). The Norms Of Entrepreneurial Science: Cognitive Effects Of The New UniversityIndustry Linkages. Research Policy, 27(8), 823-833. doi: 10.1016/S0048-7333(98)00093-6

Etzkowitz, H., Webster, A., Gebhardt, C., Terra, B.R.C. (2000). The future of the university and the university of the future: evolution of ivory tower to entrepreneurial paradigm. Research Policy, 29(2), 313-330. doi: 10.1016/S0048-7333(99)00069-4

Goethner, M., Obschonka, M., Silbereisen, R.K., Cantner, U. (2012). Researchers' transition to academic entrepreneurship: Economic and psychological determinants. Journal of Economic Psychology, 33(3), 628-641. doi: 10.1016/j.joep.2011.12.002

Gulbrandsen, M., Smeby, J.-C. (2005). Industry Funding and University Professors' Research Performance. Research Policy, 34(6), 932-950. doi: 10.1016/j.respol.2005.05.004

Hayter, C.S., Nelson, A.J., Zayed, S., Connor, A.C.O. (2018). Conceptualizing academic entrepreneurship ecosystems: a review, analysis and extension of the literature. The Journal of Technology Transfer, 43, 1039-1082. doi: 10.1007/s10961-018-9657-5

Hudson, S., Meng, F., Cárdenas, D., So, K. (2017). Knowledge Transfer. Knowledge Transfer to and within Tourism. Emerald Publishing Limited, 27-35. doi: 10.1108/S2042-144320170000008003

Jain, S., George, G., Maltarich, M. (2009). Academics or entrepreneurs? Investigating role identity modification of university researchers involved in commercialization activity. Research Policy, 38(6), 922-935. doi: 10.1016/j.respol.2009.02.007 
Lai, I.K.W., Lu, T.-W. (2016). How to improve the university-industry collaboration in Taiwan's animation industry? Academic vs industrial perspectives. Technology Analysis \& Strategic Management, 28(6), 717-732. doi: 10.1080/09537325.2016.1141404

Liñán, F., Chen, Y.-W. (2009). Development and Cross-Cultural Application of A Specific Instrument to Measure Entrepreneurial Intentions. Entrepreneurship Theory and Practice, 33, 593-617. doi: 10.1111/j.1540-6520.2009.00318.x

Marszałek, A. (2014). Relacje między światem nauki i przemysłu. E-mentor, 4(56), 44-53. doi: 10.15219/ em56.1123

Marszałek, A. (2009). Uniwersytety w obliczu przemian ekonomiczno-społecznych w XXI wieku. E-mentor, 5(32), 20-27.

Miranda, F.J., Chamorro-Mera, A., Rubio, S. (2017). Academic entrepreneurship in Spanish universities: An analysis of the determinants of entrepreneurial intention. European Research on Management and Business Economics, 23(2), 113-122. doi: 10.1016/j.iedeen.2017.01.001

Nelson, R.R. (2004). The market economy, and the scientific commons. Research Policy, 33(3), 455-471. doi: $10.1016 /$ j.respol.2003.09.008

Perkmann, M., Walsh, K. (2009). The Two Faces of Collaboration: Impacts of University-Industry Relations on Public Research. Industrial and Corporate Change, 18(6), 1033-1065. doi: 10.1093/ $\mathrm{icc} / \mathrm{dtp} 015$

Philpott, K., Dooley, L., O’Reilly, C., Lupton, G. (2011). The entrepreneurial university: Examining the underlying academic tensions. Technovation, 31(4), 161-170. doi: 10.1016/j.technovation.2010.12.003

Rohrbeck, R., Arnold, H.M. (2006). Making University-Industry Collaboration Work - a Case Study on the Deutsche Telekom Laboratories Contrasted with Findings in Literature. Proceedings of ISPIM 2006 Conference Networks for Innovation, Athens, Greece, June, pg. 11. SSRN Electronic Journal July. Retrieved from: file:///C:/Users/oland/AppData/Local/Temp/MPRA_paper_5470.pdf

Rossi, F., Rosli, A., Yip, N. (2017). Academic engagement as knowledge co-production and implications for impact: Evidence from Knowledge Transfer Partnerships. Journal of Business Research, 80, 1-9. doi: 10.1016/j.jbusres.2017.06.019

Rothaermel, F.T., Agung, S.D., Jiang, L. (2007). University entrepreneurship: A taxonomy of the literature. Industrial and Corporate Change, 16(4), 691-791. doi: 10.1093/icc/dtm023

Saeed, S., Yousafzai, S.Y., Yani de Soriano, M., Muffatto, M. (2015). The role of perceived university support in the formation of students' entrepreneurial intention. Journal of Small Business Management, 53(4), 1127-1145. doi: 10.1111/jsbm.12090

Shane, S. (2004). Encouraging university entrepreneurship? The effect of the Bayh-Dole Act on university patenting in the United States. Journal of Business Venturing, 19(1), 127-151. doi: 10.1016/ S0883-9026(02)00114-3

Siegel, D.S., Waldman, D., Atwater, L., Link, A.N. (2004). Toward a model of the effective transfer of scientific knowledge from academicians to practitioners: qualitative evidence from the commercialization of university technologies. Journal of Engineering and Technology Management, 21(12), 115-142. doi: 10.1016/j.jengtecman.2003.12.006

Sobaih, A.E., Jones, E. (2015). Bridging the hospitality and tourism university-industry research gap in developing countries: The case of Egypt. Tourism and Hospitality Research, 15(3), 161-177. doi: $10.1177 / 1467358415578188$

Van Looy, B., Ranga, M., Callaert, J., Debackere, K., Zimmermann, E. (2004). Combining entrepreneurial and scientific performance in academia: towards a compounded and reciprocal Mattheweffect?. Research Policy, 33(3), 425-441. doi: 10.1016/j.respol.2003.09.004

Welsh, R., Glenna, L., Lacy, W., Biscotti, D. (2008). Close enough but not too far: Assessing the effects of university-industry research relationships and the rise of academic capitalism. Research Policy, 37(10), 1854-1864. doi: 10.1016/j.respol.2008.07.010 
Wiśniewska, D.M. (2014). Przedsiębiorczość uczelni wyższej jako wyzwanie współczesności - kierunki zmian. Horyzonty Wychowania, 13(28), 33-49.

Marcin Olszewski, $\mathrm{PhD}$, is an Assistant Professor in the Department of International Economics at the Poznan University of Economics and Business, Poland. He finished his PhD in 2011 with a doctoral thesis on knowledge management in the hospitality industry. His research areas include university-industry collaboration, knowledge management, tourism industry competitiveness, the economics of tourism enterprise. He participated in several research projects on the tourism and hospitality industry (including those financed by the Ministry of Science and Higher Education and the National Science Center). He is an author or co-author of more than 50 papers (chapters in scientific monographs, articles in scientific journals and conference papers).

ORCID: https://orcid.org/0000-0001-9041-9953

\section{Address:}

Uniwersytet Ekonomiczny w Poznaniu Instytut Gospodarki Międzynarodowej

Katedra Międzynarodowych Stosunków Gospodarczych

al. Niepodległości 10

61-875 Poznań, Polska

e-mail: marcin.olszewski@ue.poznan.pl

This publication was created thanks to the research project "Knowledge transfer from universities to enterprises conditions and importance for the innovation of the tourism industry" (UMO-2014/15/D/HS4/01217), financed by the National Science Center. 